\title{
Reproductive biology of Lagocephalus scelertaus in Mediterranean and Red Seas,
} Egypt

\author{
Amira A. Ali ${ }^{1}$; Azza A. El- Ganainy ${ }^{2}$; Ashraf I. Ahmed ${ }^{1}$, Mohammed I. Ahmed ${ }^{1}$ \\ 1-Marine science departement, Faculty of Science, Suez Canal Univercity, \\ Ismailia, Egypt. \\ 2- Fisheries Division at National Instiute of Oceanography and Fisheries, \\ Egypt. \\ Corresponding auther: amiramowafy@yahoo.com
}

\begin{abstract}
Study of the reproductive biology of the Lessepsian migrant pufferfish species Lagocephalus sceleratus was carried out for two different populations; the first representative the native population in the Gulf of Suez (Red Sea), while the other one representative to the migrant population in the Egyptian Mediterranean Sea. The samples collected seasonally for two populations from winter 2013 till autumn 2014. The sex ratio (Males: Females) throughout study period were found 1:1.07 and 1: 1.29 for Gulf of Suez and Mediterranean population respectively. Males matured earlier in life than females in both study areas. For Gulf of Suez population, the fish length at first sexual maturity (L50) was $36.3 \mathrm{~cm}$ for males and $37.1 \mathrm{~cm}$ for females, while for Mediterranean population the fish length (L50) were 32.5 and $36.3 \mathrm{~cm}$ for males and females respectively. According to the present results of seasonal variations in maturity stages and Gonado Somatic Index (GSI) the reproductive season of Lagocephalus sceleratus collected from Gulf of Suez and Alexandria, Egyptian Mediterranean waters exhibits a relatively prolong spawning season extending from spring to summer for both sexes. In the current study, the absolute fecundity of $L$. sceleratus, for both study areas, increased with increasing in length and weight. The relative fecundity also showed slightly increase with the increase in length, while it showed small fluctuations combined with decrease particularly of largest weight fish groups with the increase in total weight.
\end{abstract}

Keyword: Lagocephalus sceleratus, Gulf Suez, Red Sea, Mediterranean Sea, Reproductive

\section{INTRODUCTION}

The ongoing influx of Red Sea biota into the Mediterranean Sea since the opening of the Suez Canal has drawn the attention of the scientific community (Por 1978; Galil 2009; Golani 2010). This phenomenon incorporates almost all marine taxonomic groups. Invasive alien species are key drivers of human - caused global environmental change (Pejchar and Money 2009). Many species have negative socioeconomic effect on the area: they have not commercial value such as Lagocephalus sceleratus, and their large populations are mainly sustained by intensive feeding on native commercial fishes and invertebrate stocks like cephalopods locally exploited and economically important in fisheries. Lessepsians feed also on large quantities of benthic invertebrates, fish and macrophytes, fundamental members of the marine food web although they are not commercially important.

Many puffer fish species migrated recently to the Mediterranean Sea via Suez Canal; hence the number of these species has been increased. Family Tetraodontidae is represented by 10 species in the Mediterranean Sea (Migratory and native). The 
population characteristics of fishes, and in particular those concerning their reproduction, are very important inputs in the assessment and management of fish stocks (Froese, 2004). With the decline in world fish stocks, our knowledge of fish reproduction has become fundamental. Reproduction is an essential commitment to future generation. The success of any fish species is ultimately determined by the ability of its members to reproduce successfully in a fluctuating environment (Moyle and Cech, 1982). So, the study of fish reproduction is considered one of the most important step to understand the fish population dynamics, such as the maturation of oocytes, the size and age at first maturity and fecundity (West, 1990).

Reproductive biology descriptors of Lagocephalus sceleratus in the Mediterranean and Red sea are limited (Golani et al., 2006; Sabrah et al., 2006; Aydin, 2011 and Nader et al.; 2012; Farrag, 2014).

The aim of this work is to increases the knowledge on the reproductive biology of the puffer fish L. sceleratus along the Gulf of Suez and the Mediterranean coasts of Alexandria by studying sex ratio, seasonally changes in maturity stages and changes in maturation at different sizes. In addition to study Gonado- Somatic Index (GSI) and fecundity per length and weight.

\section{MATERIALS AND METHODS}

\section{Study area and sampling}

Fishing and landing of puffer fishes are prohibited all over Egypt by the Egyptian law (GAFRD, 2008) and the decree No. 665 for 2013 by the Ministry of Commerce. The collection of samples was very difficult. Lagocephalus sceleratus were collected randomly from two different populations. The first population was collected seasonally from commercial catches at the Attaka fishing harbor in Suez from winter 2013 till autumn 2014 and the second population was collected from Alexandria at the same period. Samples collected from Suez represented Gulf of Suez (Red Sea), while the other one represented the Egyptian Mediterranean Sea. The species was caught by trawling or purse seines in the two studied sites (Fig. 1). In total, 365 individuals were analyzed; 186 collected from the Gulf of Suez and 179 from the Mediterranean. All the specimens were stored at $-20^{\circ} \mathrm{C}$ immediately after collection to avoid contraction.

\section{Reproductive measurements}

\section{1- Sex ratio}

The sex ratio of fish population refers to the frequency or the percentages of males to females in population or catch. Sex was determined visually. Chi square test at 0.05 significance level was computed according to Snedecor (1956).

\section{2- First sexual maturity}

The length at first sexual maturity is defined as the length at which $50 \%$ of fish reach sexual maturity (Pitt, 1970). The length at first sexual maturity $\left(\mathrm{L}_{\mathrm{m}}\right)$; the length at which $50 \%$ of $L$. sceleratus reach their sexual maturity was estimated by fitting the percentage maturity against mid lengths (King, 1995). $\mathrm{L}_{m}$ was estimated as the point on $\mathrm{X}$-axis corresponding to $50 \%$ point on $\mathrm{Y}$-axis, while the corresponding age at first sexual maturity $\left(\mathrm{t}_{\mathrm{m}}\right)$ was computed by converting $\mathrm{L}_{\mathrm{m}}$ to age using the von Bertalanffy growth equation as follows:

$$
\mathrm{t}_{\mathrm{m}}=\mathrm{t}_{0}-\left(1 / \mathrm{K} * \ln \left[1-\left(\mathrm{L}_{\mathrm{m}} / \mathrm{L}_{\infty}\right)\right]\right)
$$

Where, $\mathrm{t}_{\mathrm{m}}=$ Age at first sexual maturity, $\mathrm{t}_{0}=$ the age for the fish would have had at length zero ( $t_{0}$ generally has a negative value), $\mathrm{K}=$ growth coefficient, $\mathrm{Lm}=$ the length at first sexual maturity, $\mathrm{L} \infty=$ the theoretical maximum length (asymptotic length, 
that's mean length of the fish would reach if they were grow to a very old age, indefinitely in fact).

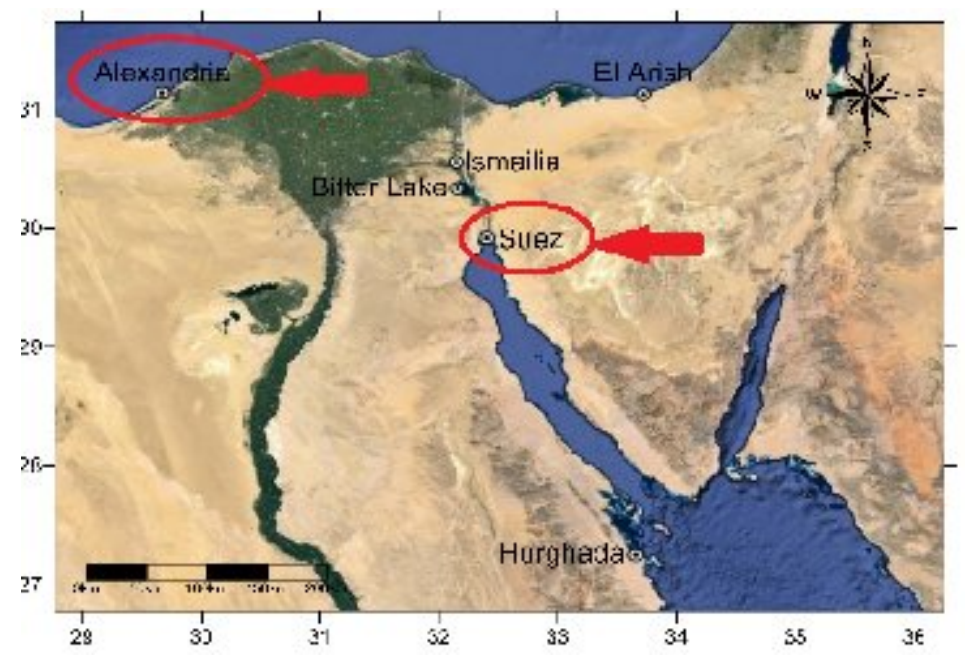

Fig. 1: Sampling sites at Red Sea and Mediterranean Sea.

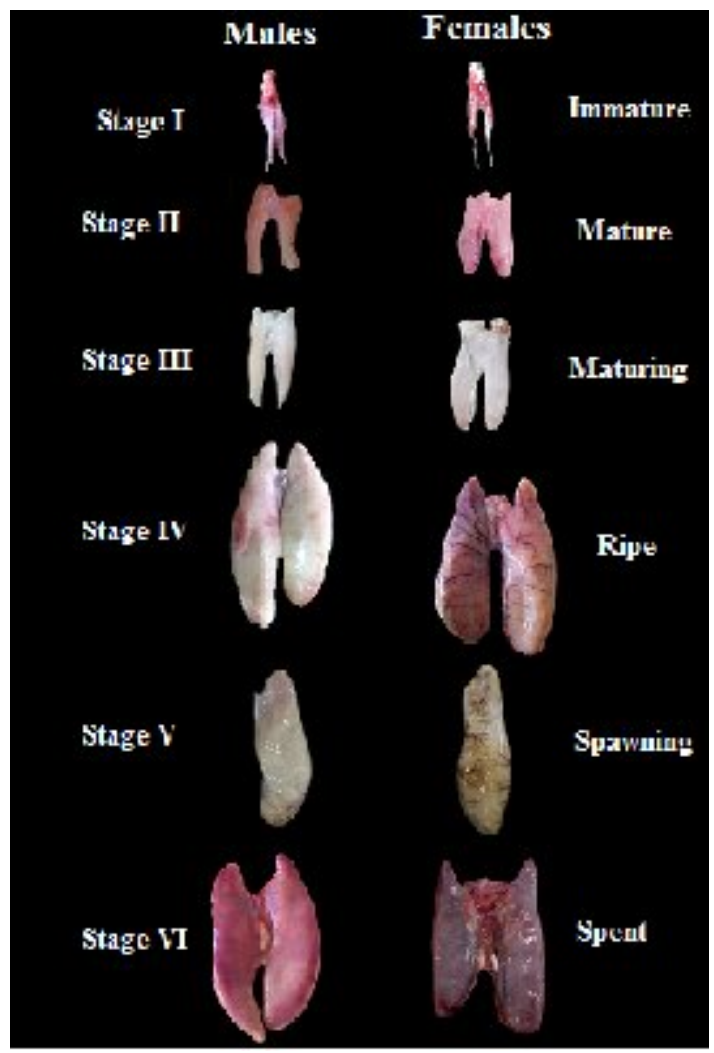

Fig. 2: Different maturity stages of males and females of Lagocephalus sceleratus.

\section{3- Variations of maturity stages}

The seasonal reproductive strategy of Lagocephalus sceleratus from Gulf of Suez and the Egyptian Mediterranean waters were studied. The maturity stages were observed for males and females and classified according to modified scale of Nikolsky (1963) into six maturity stages. 


\section{4- Gonado- Somatic Index (G.S.I.)}

The spawning season was determined following the seasonally changes of the gonado somatic index (GSI), calculated as follows:

$$
\text { GSI }=100 \mathrm{GW} / \mathrm{Twt} \text { (Anderson and Gutreuter, 1983) }
$$

Where GW is the gonad weight and Twt is the total fish weight.

\section{5- Fecundity}

Fecundity was estimated by counting all ripe eggs found in the female ovary just prior to spawning season.

Fecundity per length and fecundity per weight was applied in studying fish fecundity (Simpson, 1951 and Nikolosky, 1963). The relationships between these two variables and fecundity were estimated according to the following formula: $\mathbf{A F}=\mathbf{a} \mathbf{X}^{\mathbf{b}}$

Where, $\mathrm{AF}=$ absolute fecundity, $\mathrm{X}=$ independent variable (length or weight), $\mathrm{a}=$ constant and $\mathrm{b}=$ exponent value (Bagenal, 1978).

\section{RESULTS AND DISCUSSION}

\section{1- Sex ratio}

The sex ratio (males: females) for L. sceleratus through the study period were female biased by 1:1.07 and 1:1.29 for Gulf of Suez and Mediterranean populations, respectively. Chi- square test showed significance difference between males and females numbers in each studied site $\left(X^{2}=0.194, P<0.05\right)$ and $\left(X^{2}=2.955, P<0.05\right)$ for Gulf of Suez and Mediterranean Sea populations, respectively. These findings agreed with that reported by Sabrah et al. (2006) from Red Sea which was 1: 1.3 and differed from Farrag (2014) in Mediterranean water, who found that the ratio was male biased (1:0.91). This difference may be relate to the variance in the availability of both sexes for the fishery, and to the spatial segregation of sexes or a feeding behavior (Korpelainen, 1991 and Mendonca et al., 2006).

The seasonal variations in the sex ratios of $L$. sceleratus collected from Gulf of Suez population and Mediterranean Sea population are given in Tables (1) and (2), respectively.

Table 1: Seasonal variations of sex ratio of Lagocephalus sceleratus collected from Gulf of Suez during the period from winter 2013 to autumn 2014.

\begin{tabular}{|c|c|c|c|c|c|c|c|}
\hline \multirow{2}{*}{ Season } & \multirow{2}{*}{ Frequency } & \multicolumn{2}{|c|}{ Males } & \multicolumn{2}{c|}{ Females } & Sex ratio & \multirow{2}{*}{$\boldsymbol{X}^{2} *$} \\
\cline { 3 - 8 } & & Freq. & $\mathbf{\%}$ & Freq. & $\mathbf{\%}$ & M:F & \\
\hline Winter & 55 & 32 & 58.2 & 23 & 41.8 & $1: 0.72$ & 1.473 \\
\hline Spring & 39 & 19 & 48.7 & 20 & 51.3 & $1: 1.05$ & 0.026 \\
\hline Summer & 52 & 21 & 40.4 & 31 & 59.6 & $1: 1.48$ & 1.923 \\
\hline Autumn & 40 & 18 & 45.0 & 22 & 55.0 & $1: 1.22$ & 0.400 \\
\hline Total & 186 & 90 & 48.39 & 96 & 51.61 & $1: 1.07$ & 0.194 \\
\hline
\end{tabular}

Table 2: Seasonal variations of sex ratio of Lagocephalus sceleratus collected from the Egyptian Mediterranean waters during the period from winter 2013 to autumn 2014.

\begin{tabular}{|c|c|c|c|c|c|c|c|}
\hline \multirow{2}{*}{ Season } & \multirow{2}{*}{ Frequency } & \multicolumn{2}{|c|}{ Males } & \multicolumn{2}{|c|}{ Females } & \multirow{2}{*}{$\begin{array}{c}\text { Sex ratio } \\
\text { M:F }\end{array}$} & \multirow{2}{*}{$X^{2 *}$} \\
\hline & & Freq. & $\%$ & Freq. & $\%$ & & \\
\hline Winter & 86 & 29 & 33.7 & 57 & 66.3 & $1: 1.97$ & 9.116 \\
\hline Spring & 30 & 15 & 50.0 & 15 & 50.0 & $1: 1.00$ & 0.000 \\
\hline Summer & 46 & 30 & 65.2 & 16 & 34.8 & $1: 0.53$ & 4.261 \\
\hline Autumn & 17 & 4 & 23.5 & 13 & 76.5 & $1: 3.25$ & 4.765 \\
\hline Total & 179 & 78 & $\begin{array}{ll}43.58 \\
\end{array}$ & 101 & 56.42 & $1: 1.29$ & 2.955 \\
\hline
\end{tabular}




\section{2-Size and age at first sexual maturity ( $L_{50}$ and $\left.t_{50}\right)$}

The length at first sexual maturity $\left(\mathrm{L}_{50}\right)$ is very important parameter in fisheries research to assess the optimum age of first capture of a species or to determine minimum legal size that may be needed to maintain the suitable spawning (Farrag, 2008).

In the present work, males matured earlier in life than females in both study areas. For Gulf of Suez population, the fish length $\left(\mathrm{L}_{50}\right)$ was $36.3 \mathrm{~cm}$ for males and $37.1 \mathrm{~cm}$ for females, while for Egyptian Mediterranean population the average maturation length $\left(\mathrm{L}_{50}\right)$ was 32.5 and $36.3 \mathrm{~cm}$ for males and females, respectively (Figs. 3 and 4). The Mediterranean population attains $\mathrm{L}_{50}$ earlier than Gulf of Suez population, may be related to the favorable conditions, food availability in such area of sub-tropical to temperate zones especially this species $L$. sceleratus established itself well along the different coasts of Mediterranean basin according to their ability as a member of open water hunters (Kalogirou, 2013; Farrag, 2014 and Rousou et al., 2014).
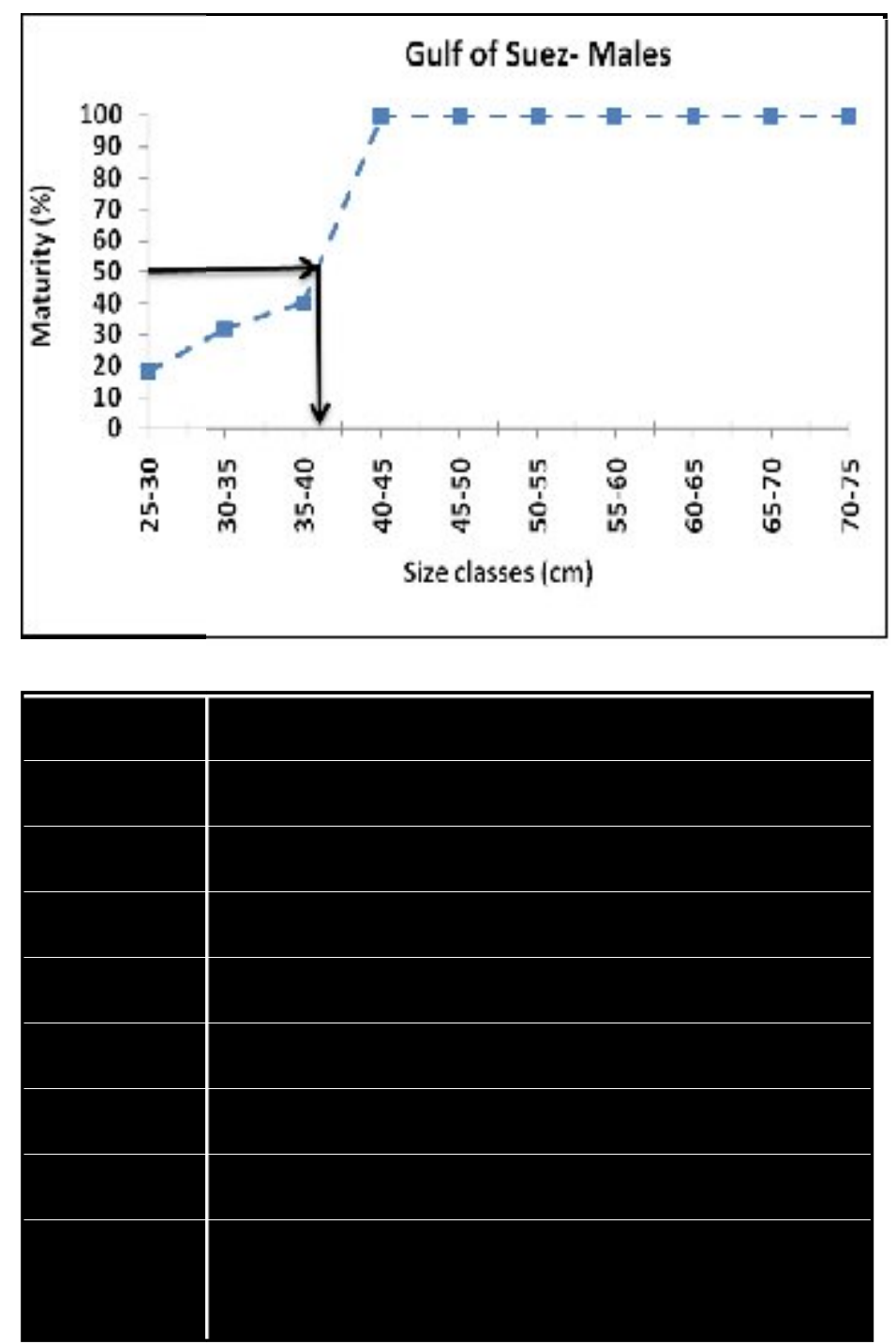

Fig 3: Length at first sexual maturity for both sexes of Lagocephalus sceleratus collected from Gulf of Suez during the period from winter 2013 to autumn 2014. 

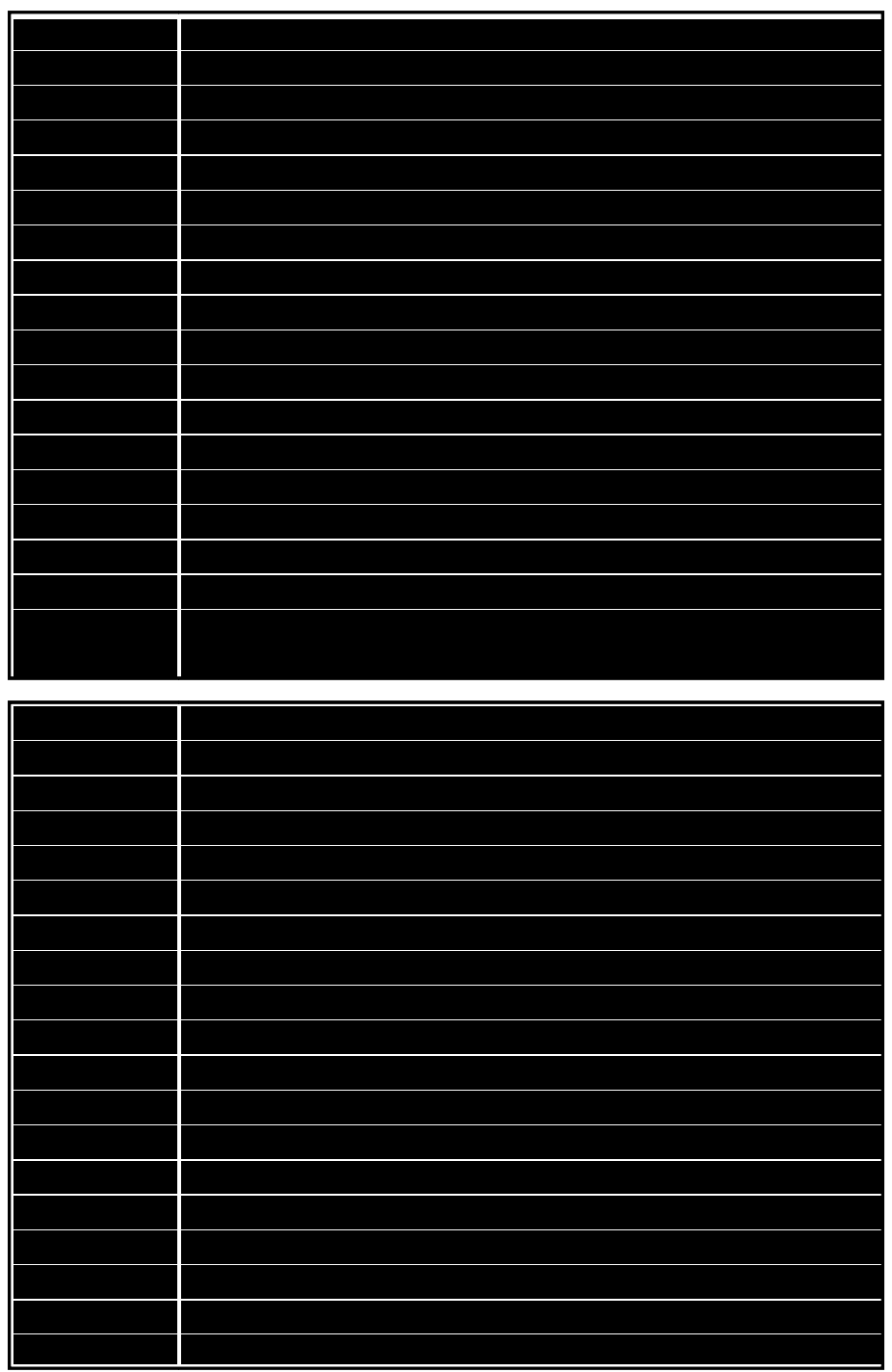

Fig. 4: Length at first sexual maturity for both sexes of Lagocephalus sceleratus collected from the Egyptian Mediterranean waters during the period from winter 2013 to autumn 2014.

These results were agreed with the value of $\mathrm{L}_{50}$ obtained by Kalogirou (2013) from Rhodes Island, Eastern Mediterranean Sea, it was only $36 \mathrm{~cm}$ for combined sexes of the same species. While in the present results LSO was lower than those obtained by Sabrah et al. (2006) for the same species from Red Sea, Egypt, where the authors showed that the size at which $50 \%$ of fishes became mature were $42.1 \mathrm{~cm}$ and $43.3 \mathrm{~cm}$ for males and females, respectively. Farrag (2014) found that $\mathrm{L}_{50}$ was $38.5 \mathrm{~cm}$ for males and $41 \mathrm{~cm}$ for females for the same species from Egyptian Mediterranean waters. Also, Rousou et al. (2014) estimated $\mathrm{L}_{50}$ of L. sceleratus from southwestern (SWA) and the south-east (SEA) coastal areas of Cyprus, and found that the individuals reached first maturity $\left(\mathrm{L}_{50}\right)$ at $41.9 \mathrm{~cm}$ for the SWA and $48.8 \mathrm{~cm}$ for the SEA populations. The difference in maturity size may be related to the environmental condition specially temperature, which induced phenotypic flexibility (genetic differences) in fish which may change size at maturity (Pyper et al., 1999), or it may also due to different habitat, the variation in number of specimens and size range.

\section{3- Seasonal variations in maturity stages}

For Gulf of Suez population, the immature stages were recorded in three seasons for males and two seasons for females. The period of spawning of $L$. 
sceleratus started in spring where the ripe gonads started to be found in the samples and amounted $31.58 \%$ and $34.62 \%$ for males and females respectively. This stage extended but decreased in its percentages by $14.29 \%$ and $29.17 \%$ for males and females respectively until summer revealing to a prolonged spawning season of $L$. Sceleratus (Fig. 5).
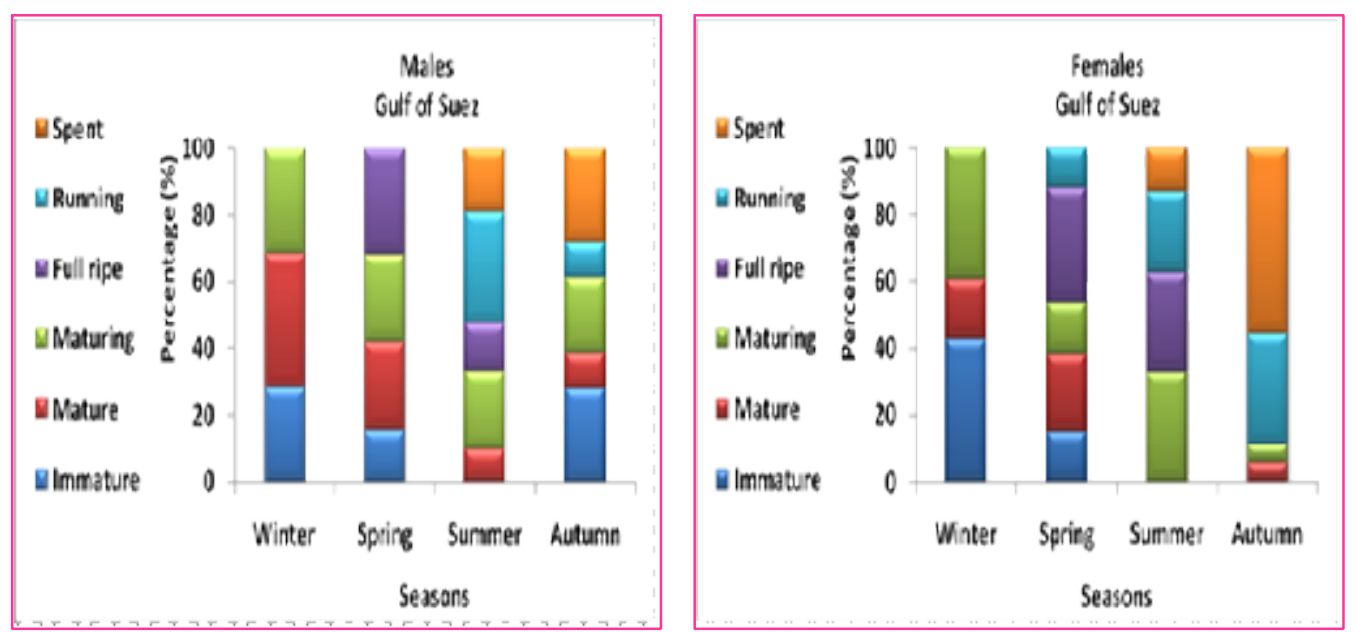

Fig. 5: Seasonal variations of maturity stages for both sexes of Lagocephalus sceleratus collected from Gulf of Suez, during the period from winter 2013 to autumn 2014.

For Egyptian Mediterranean waters population, according to seasonal variations of maturity stages, it was noticed that, spawning season extended from spring to summer in both sex. Running (spawning) stage appeared in spring by $6.7 \%$ for both sexes and extended to summer, while spent stages extended to autumn (Fig. 6).

The seasonal variations of the different maturity stages and their distribution throughout the study period, reflects the time of spawning. In the present study, for Gulf of Suez population, immature stages were found in almost all the year for both sexes, while the ripe stage of $L$. sceleratus started to appear in spring for both sexes and continued until summer.
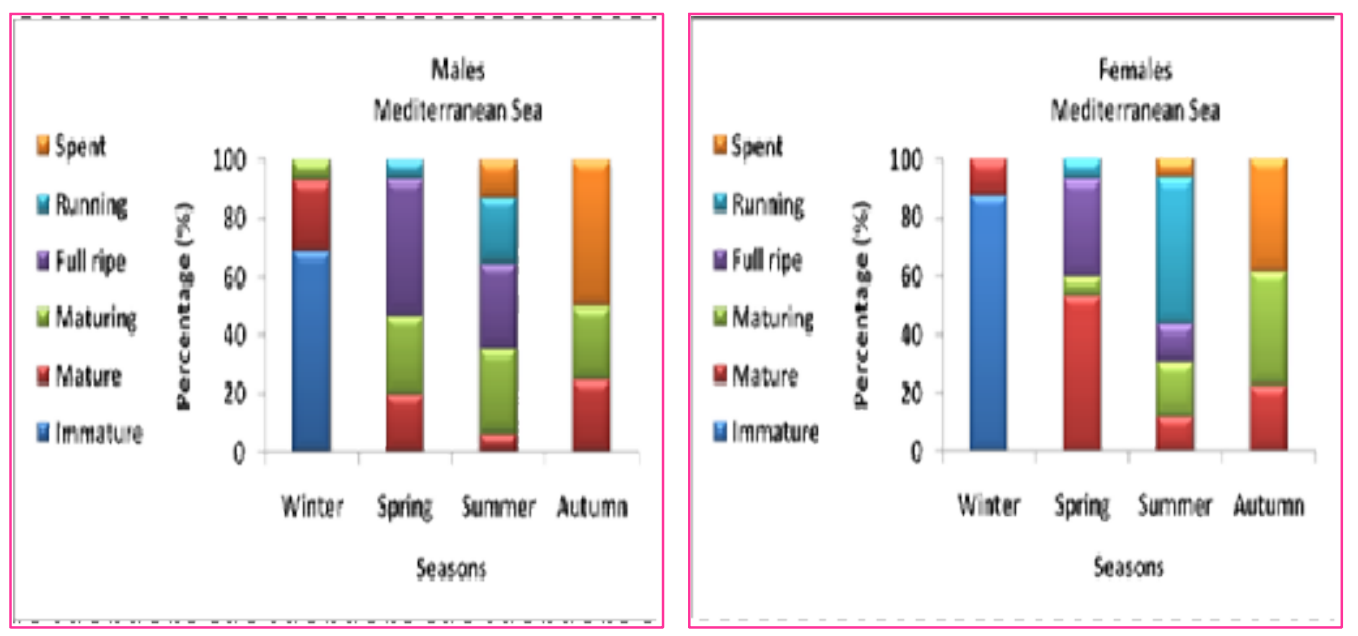

Fig. 6: Seasonal variations of maturity stages for both sexes of Lagocephalus sceleratus collected from the Egyptian Mediterranean waters during the period from winter 2013 to autumn 2014.

While for Alexandria, Egyptian Mediterranean population, the immature stage was present in winter samples for both sexes and the mature stage was recorded in all of the year, also ripping testes and ovaries were present in spring and continued till 
summer for both sexes. This means that L. sceleratus in the present study has a prolonged spawning season in both study areas.

\section{4- Gonado Somatic Index (GSI)}

Females acquired higher average values of GSI than males except in spring in which males recorded slightly higher values of GSI $(1.732 \pm 2.409)$ than females $(1.641 \pm 1.985)$. The trend of average value of GSI for males and females were nearly similar; average value of GSI started to increase in winter reached its peak in spring, then GSI value decreased reaching its minimum value in summer $(0.392 \pm 0.494$ for males and $(0.898 \pm 0.420)$ for females (Fig. 7$)$.

The maximum average values of GSI for both sexes were recorded in spring season $(2.141 \pm 3.020)$ for males and $(3.168 \pm 5.575)$ for females. The average values of GSI for both sexes were during summer and autumn until it reached the minimum values in winter $(0.143 \pm 0.061)$ for males and $(0.122 \pm 0.065)$ for females. These results showed that, the spawning season of Lagocephalus sceleratus in both study areas was the in spring for both sexes (Fig. 8).

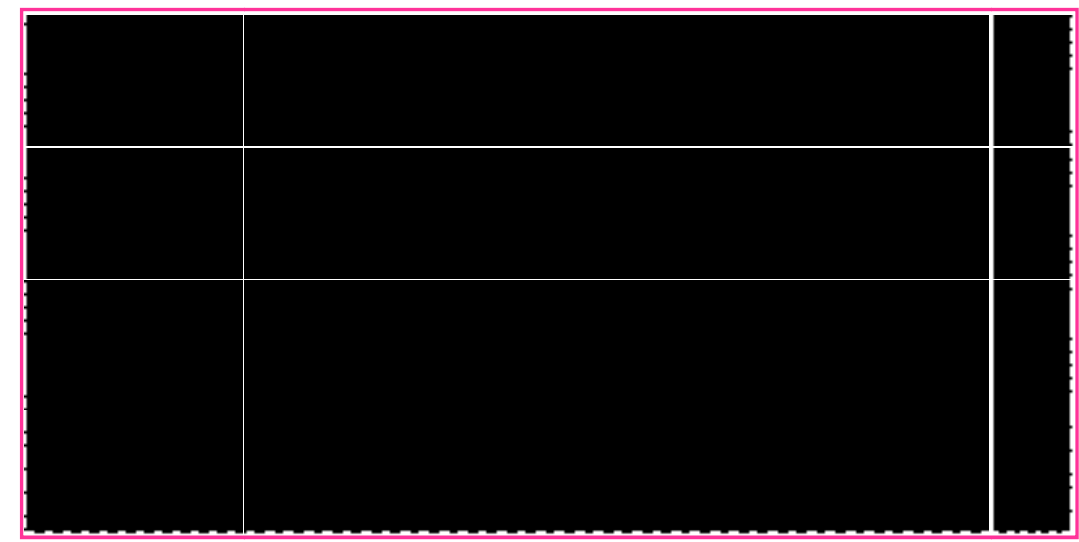

Fig. 7: Seasonal variations of Ganado-Somatic-Index (GSI) for separate sexes of Lagocephalus sceleratus collected from Gulf of Suez during the period from winter 2013 to autumn 2014.

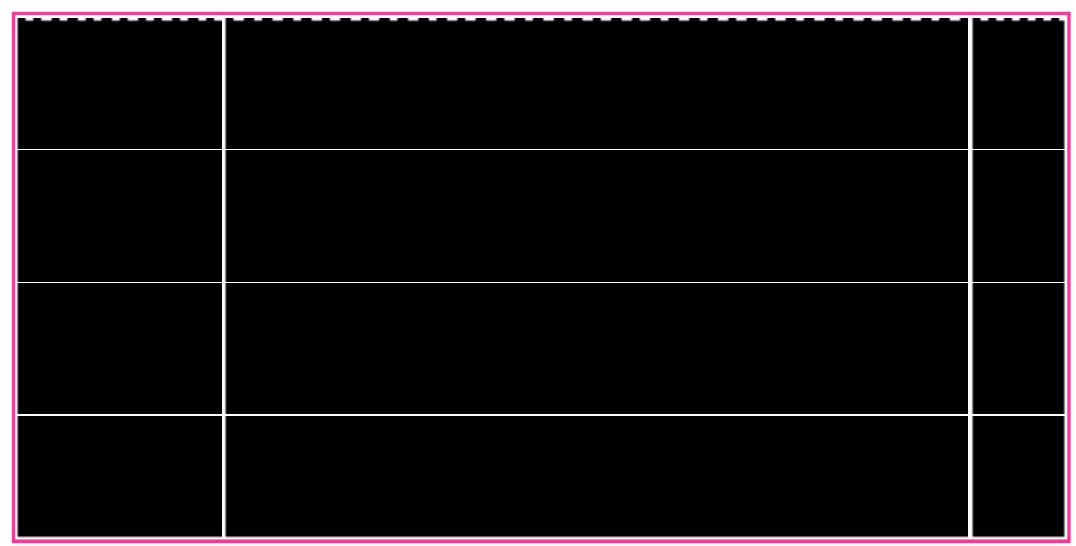

Fig. 8: Variations of Ganado- Somatic- Index (GSI \%) for separate sexes of Lagocephalus sceleratus collected from the Egyptian Mediterranean waters during the period from winter 2013 to autumn 2014.

Gonado somatic index (GSI) has been widely used as an indicator of reproductive condition and spawning time in fishes (Plaza et al., 2007). In the current study, the maximum values of GSI values of $L$. sceleratus were recorded in spring season for both study areas and the rates of GSI values were higher in females than males. The results indicated that GSI values recorded in Mediterranean population 
were higher than that found in original habitat Gulf of Suez. Regarding the mode of GSI values and its fluctuations along the period for both sexes, Moyle and Cech (2004) stated that the ovaries of teleost fishes are larger several times than the testes. So, the GSI is almost higher for females than males, particularly during spawning season which is opposite to Gulf of Suez population result. Such finding was reported for some fishes such as the round herring Etrumeus teres by El-Sayed (1996); Farrag (2010) and Osman et al. (2011).

According to the present result of seasonal variations in maturity stages and (GSI) the reproductive season of L. sceleratus collected from Gulf of Suez and Alexandria, Egyptian Mediterranean waters were found to extend from spring to summer which is in agreement with the observations of Aydin (2011) in Antalya Bay, Kalogirou (2013) in Greece, Sabrah et al. (2006) in the Gulf of Suez and Farrag (2014) in Egyptian Mediterranean waters. Also Rousou et al. (2014) reported that, the reproductive season of $L$. sceleratus off Cyprus was found to extend from late spring to middle summer.

\section{5-Fecundity}

In the present work, the absolute fecundity of $L$. sceleratus for both study areas, increased with increasing in length and weight. The relative fecundity also showed slightly increase with the increase of length, while it showed small fluctuations combined with decrease particularly of largest weight fish groups with the increase in total weight. Oso et al. (2011) reported that, these fluctuations may be attributed to the presence of individual variations in the well being which may cause fluctuation in fecundity in relation to weight and they added that the weight is more related to fecundity than length, although both have a positive relationship with fecundity. Also, this may indicate that the oldest fishes had relative fecundity lower than young mature individuals.

The present work showed that the average absolute fecundity of L. sceleratus for Gulf of Suez was $1549720 \pm 798862$ and averages of relative fecundity were $25421 \pm 10071 \mathrm{ova} / \mathrm{cm}$ and $619 \pm 105 \mathrm{ova} / \mathrm{g}$ (Figs. 9 and 10). For Egyptian Mediterranean population, the average absolute fecundity was $1583370 \pm 648922$, while averages of relative fecundity were $27269 \pm 8878 \mathrm{ova} / \mathrm{cm}$ and $854 \pm 294 \mathrm{ova} / \mathrm{g}$. (Figs. 11 and 12).

These results are in agreement with that reported by Aydin (2011) from Turkish water, who stated that the relative fecundity was $780.8 \pm 171.8 \mathrm{ova} / \mathrm{g}$ (minimum value was 566.4 and maximum $1061.1 \mathrm{ova} / \mathrm{g}$ ) total body weight.

The results were slightly lower than that obtained by Farrag (2014) from Egyptian Mediterranean waters, who found that, the absolute fecundity range was from 260288 to 2372931 for fish weight ranged from 698 to $3285 \mathrm{~g}$ with an average of $1449522 \pm 720975$. The relative fecundity ranged from 373 to 722 with an average of $776 \pm 231$ ova in each gram gutted weight for fish weight ranged from 698 to $3285 \mathrm{~g}$. The difference in number may be attributed to the use of gutted body weight by Farrag (2014) instead of total weight that used in the present work.

By comparing the absolute and relative fecundity for the two studied populations, the results showed that the number of ova of L. sceleratus were higher in Egyptian Mediterranean habitat than that recorded in the Gulf of Suez. The differences between the two populations for the same length group may be related to environmental factors (Hay et al., 1987 and Plaza et al., 2007). Also, Farrag (2014) reported that, this species as immigrant species gave large number of ova with determinate fecundity during spawning season indicating that this species established itself well in new habitats and predicted to be increased in its abundance. 


\section{REFERENCES}

Anderson, R. O. and Guteruter, S. J. (1983). Length, weight, and associated structural indices. In: L. A. Neilsen and D. L. Johnson (Eds), Fisheries Techniques. American Fisheries Society, Bethesda: pp.283-300.

Aydin, M. (2011). Growth, reproduction and diet of pufferfish (Lagocephalus sceleratus Gmelin, 1789) from Turkey's Mediterranean Sea coast. Turkish Journal of Fisheries and Aquatic Sciences, 11: 589-596.

Bagenal, T. B. (1978). Methods for Assessment of Fish Production in Fresh Waters. 3rd Ed., Handbook No:3, Blackwell Scientific Publication, Oxford, 365 pp.

El-Sayed, A. Y. (1996). Biological and Ecological studies on purse-seine fisheries in the Gulf of Suez. Ph.D. Thesis, Zoology Department, Faculty of Science, Suez Canal University, Ismailia, Egypt.

Farrag, E. F. E. (2008). Population dynamics and management of some sparid fish species in Abu Qir- Bay. M.Sc. Thesis, Faculty of science, Al-Azhar University, Egypt.

Farrag, M. M. S. (2010). Fishery biology of Red Sea immigrant Etrumeusteres (Family: Clupeidae) in the Egyptian Mediterranean water, off Alexandria. M.Sc. Thesis, Faculty of science, Al- Azhar University; Assuit Branch; Faculty of Science; Zoology Department.

Farrag, M. M. S. (2014). Fisheries and Biological studies on Lessepsian puffer fish, Lagocephalus sceleratus (Gmelin, 1789) (Family: Tetraodontidae) in the Egyptian Mediterranean Waters. Al- Azhar University; Assuit Branch; Faculty of Science; Zoology Department.

Froese R. (2004). Keep it simple: three indicators to deal with overfishing. Fish and Fisheries, 5(1):86-91.

Galil, B. (2009). An examination of the genus Philyra Leach, 1817 (Crustacea, Decapoda, Leucosiidae) with description of seven new genera and six new species. Zoosystema, 31: 279-320.

Golani, D.; Öztürk, B. and Başusta, N. (2006). Fishes of the eastern Mediterranean. Turkish Marine Research Foundation, Istanbul, $260 \mathrm{pp}$.

Golani, D. (2010). Colonization of the Mediterranean by Red Sea fishes via the Suez Canal-Lessepsian migration. In: Golani D, Appelbaum-Golani B (eds), Fish Invasions of the Mediterranean Sea: Change and Renewal. Pensoft Publishers, Sofia-Moscow, pp. 145-188.

Hay, D.E.; Qutran, D.N. and Hurtlber, M. (1987). Ovarian development and oocyte diameter as maturation criteria in pacific herring (Clupea harengus pallasi). Canadian Journal of Fisheries and Aquatic science, 44: 1181-1194.

Kalogirou, S. (2013). Ecological characteristics of the invasive pufferfish Lagocephalus sceleratus (Gmelin, 1789) in Rhodes, Eastern Mediterranean Sea. A case study Mediterranean Marine Science Indexed in WOS (Web of Science, ISI Thomson) and SCOPUS .

King, M. (1995). Fisheries biology, assessment and management. Fishing New Books, $341 \mathrm{pp}$.

Korpelainen, H. (1991). Sex ratio variation and spatial segregation of the sexes in populations of Rumex acetosa and R. Acetosella (Polygonaceae). Pl. Syst. Evol., 174: 183-195.

Mendonca, A.; Isidro, E.; Menezes, G.; Pinho, M.R.; Melo, O. and Estacio, S. (2006): New contribution to the reproductive features of bluemouth Helicolenus 
dactylopterus dactylopterus from the northeast Atlantic (Azores Archipelago). Scienta Marina, 70: 679-688.

Moyle, B. P. and Cech, J. J. (1982). Fishes: An Introduction to Ichthyology. Prentice Hall, New Jersey.

Moyle, B. P. and Cech, J. J. (2004). Fishes, an introduction to ichthyology. Prentice Hall, Upper Saddle River, NJ, USA. 726 pp.

Nader, M.; Indary, S. and Boustany, L. (2012). FAO EastMedThe Puffer Fish Lagocephalus sceleratus (Gmelin, 1789) in the Eastern Mediterranean. GCP/INT/041/EC - GRE -ITA/TD-10.

Nikolsky, G. V. (1963). The ecology of fishes (Transelated from Russian) Academic press. London-New York.

Osman, A. G. M.; Akel, E. H.; Farrag, M. M. S. and Moustafa, M. A. (2011). Reproductive Biology of round herring Etrumeusteres (Dekay, 1842) from the Egyptian Mediterranean water at Alexandria. International Scholarly Research Notices (ISRN Zoology), 11: 12 pp.

Oso, J. A.; Idowu, E. O.; Fagbuaro, O.; Olaniran, T. S. and Ayorinde, B. E. (2011). Fecundity, Condition Factor and Gonado-Somatic Index ofHepsetusOdoe (African Pike) in a Tropical Reservoir, SouthwestNigeria. World Journal of Fish and Marine Sciences, 3(2): 112-116.

Pejchar, L. and Money, H. (2009). Invasive species, ecosystem services and human well-being', Trends in Ecology and Evolution, 24(9): 497-504.

Pitt, T.K. (1970). Distribution, abundance and spawning of yellow tail flounder, Limanda ferruginea, in the Newfoundland area of the North West Atlantic. Journal of Fisheries Research Board Canada, 27 (1): 2261-2271.

Plaza, G.; Sakaji, H.; Honda, H.; Hirota, Y. and Nashida, K. (2007). Spawning pattern and type of fecundity in relation to ovarian allometry in the round herring Etrumeus teres. Marine Biology, 152:1051-1064.

Por, F.D. (1978). Lessepsian migration. The influx of Red Sea biota into the Mediterranean by way of the Suez Canal. Ecological Studies, 23. SpringerVerlag, Berlin, 228 pp.

Pyper, B. J.; Peterman, R. M.; Lapointe, M. F. and Walters, C. J. (1999). Patterns of covariation in length and age at maturity of British Columbia and Alaska sockeye salmon (Oncorhynchus nerka) stocks.Canadian Journal of Fisheries and Aquatic science, 56:1046-1057.

Rousou, M.; Ganias, K.; Kletou, D.; Loucaides, A. and Tsinganis, M. (2014). Maturity of the pufferfish Lagocephalus sceleratus in the southeastern Mediterranean Sea. Sexuality and early development in aquatic organisms, 1: $35-44$.

Sabrah, M. M., El-Ganainy A. A. and Zaky, M. A. (2006). Biology and toxicity of the puffer fish Lagocephalus sceleratus (Gmelin, 1789) from the Gulf of Suez. Egypt. J. aquat. Res., 32: 283-297.

Simpson, A. C. (1951). The fecundity of the plaice. Fisheries Invest., Lond., ser. 2,17(5):1-27.

West, G. (1990). Methods of assessing ovarian development in fishes: a review. Aust. J. Mar. Fresh wat. Res. 41:199-222. 


\section{ARABIC SUMMARY}

بيولوجيا تكاثر سمكة القراض الأسود (اللاجوسيفالس اسكليراتس) في البحرين المتوسطوالأحمر،

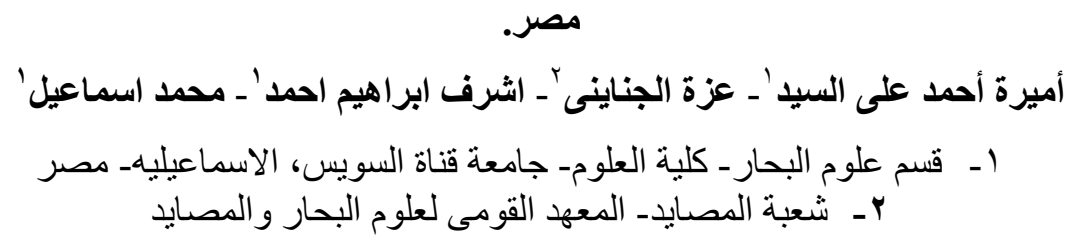

تم دراسه بيولوجيا التكاثر لاسماك لاجوسيفالاس سكليريتس فى موطنها الاصلى بخليج السويس (البحر

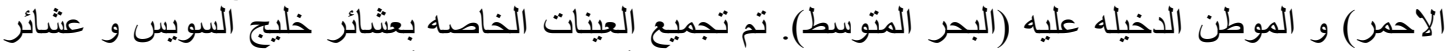

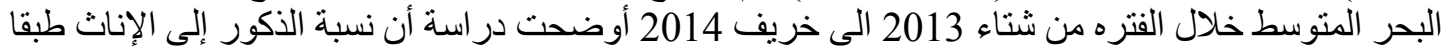

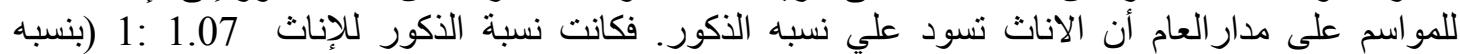

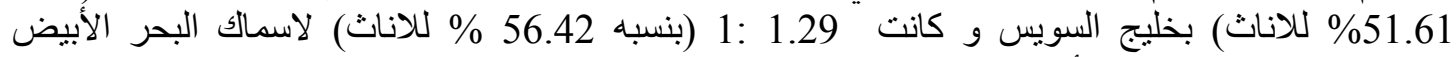

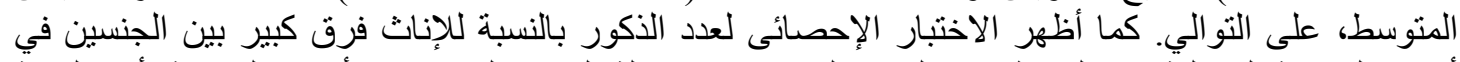

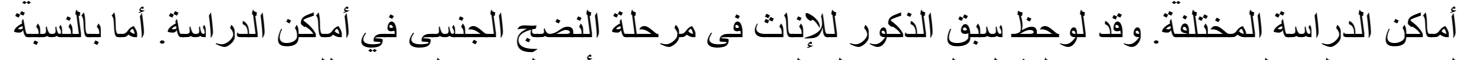

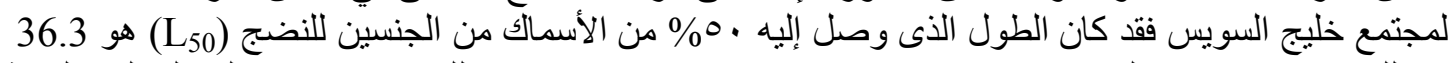

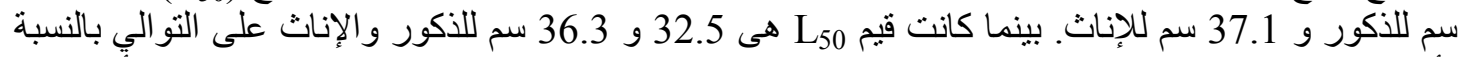

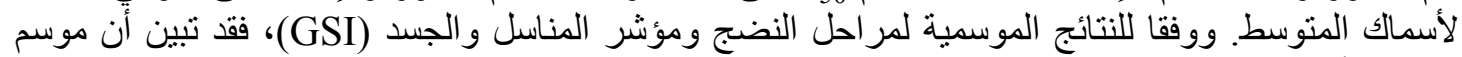

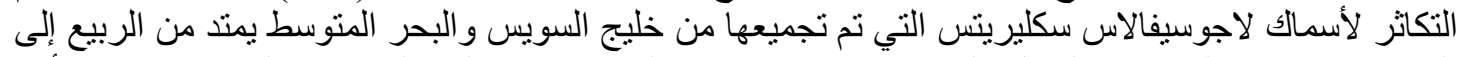

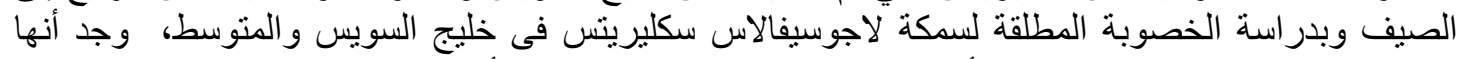

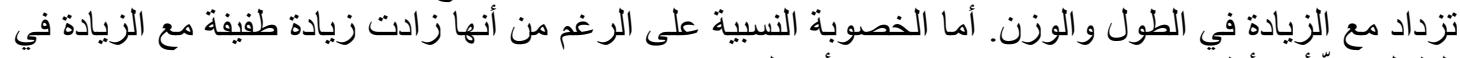
الطول، إلاّ أنها أظهرت في الطخفاض مع كبر وزن الوزن الأسماك. 